\title{
Akreditasi LIPI

\section{EFFECT OF CONCENTRATION OF IMPERATA CYLINDRICA L LEAF EXTRACT ON SYNTHESIS PROCESS OF GOLD NANOPARTICLES}

\author{
Iwan Syahjoko Saputra ${ }^{1}$, Yoki Yulizar ${ }^{2}$ dan Sudirman ${ }^{3}$ \\ ${ }^{1}$ Academy of Analytical Chemistry Caraka Nusantara \\ Jl. Tugu Raya Komplek Timah, Depok, 16951 \\ ${ }^{2}$ Departement of Chemistry, FMIPA - UI \\ Kampus Baru UI, Depok, 16424 \\ ${ }^{3}$ Center for Science and Technology of Advanced Materials - BATAN \\ Kawasan Puspiptek, Serpong 15314, Tangerang Selatan \\ E-mail :iwan_chemistry@yahoo.co.id
}

Received: 28 September 2017 Revised: 17 January 2018 Accepted: 22 January 2018

\begin{abstract}
EFFECT OF CONCENTRATION OF IMPERATA CYLINDRICA L LEAF EXTRACT ON SYNTHESIS PROCESS OF GOLD NANOPARTICLES. Gold Nanoparticles (GoldNPs) successful was performed using $\mathrm{HAuCl}_{4}$ precursor as $\mathrm{Au}^{3+}$ ion source with $7 \times 10^{-4} \mathrm{M}$ concentration. The research aims to knows effect of concentration variation of Imperata cylindrica L leaf extract on synthesis process of gold nanoparticles. The research used of green synthesis method. Colloid of nanoparticles which is formed in analyzed using UV-Vis Spectrophotometer, FT-IR Spectroscopy, PSA, PZC, XRD and TEM. The results of synthesis showed the best concentration of Imperata cilyndrica $L$ leaf extract at 3,46\%, happen a shift of wavelength at UV-Vis from $216 \mathrm{~nm}$ to $530 \mathrm{~nm}$ with 1.779 absorbance value. The PSA analysis showed a particle size of $51.87 \mathrm{~nm}$ and a PZC value of $-19.2 \mathrm{mV}$. The result of FT-IR indicated a shift of wavenumber in the hidroxyl group from $3354 \mathrm{~cm}^{-1}$ to $3390 \mathrm{~cm}^{-1}$ and showed a interaction of hydroxyl group at imperata cylindrica $\mathrm{L}$ leaf extract with $\mathrm{Au}^{3+}$ ion. TEM analysis shows the morphology of GoldNPs that spherical shape with a particle size of $20 \mathrm{~nm}$. XRD calculation results show crystallite size of gold nanoparticles is $15.47 \mathrm{~nm}$.
\end{abstract}

Keywords: Imperata cylindrica L, Gold Nanoparticles (GoldNPs), Green Synthesis

\begin{abstract}
ABSTRAK
PENGARUH KONSENTRASI EKSTRAK DAUN ILALANG (IMPERATA CYLINDRICA L) DALAM PROSES SINTESIS NANOPARTIKEL EMAS. Nanopartikel Emas (GoldNPs) berhasil dilakukan menggunakan prekursor $\mathrm{HAuCl}_{4}$ sebagai sumber ion $\mathrm{Au}^{3+}$ dengan konsentrasi $7 \times 10^{-4} \mathrm{M}$. Tujuan penelitian ini yaitu ingin mengetahui pengaruh variasi konsentrasi ekstrak daun ilalang dalam proses pembentukan nanopartikel emas. Metode yang digunakan pada penelitian ini yaitu metode green synthesis. Koloid nanopartikel yang terbentuk di karakterisasi menggunakan Spektrofotometer UV-Vis, Spektroskopi FT-IR, PSA, PZC, XRD dan $T E M$. Hasil penelitian menunjukkan konsentrasi ekstrak daun ilalang yang terbaik yaitu 3,46\% terlihat adanya pergeseran panjang gelombang pada $U V$-Vis dari $216 \mathrm{~nm}$ menjadi $530 \mathrm{~nm}$ dengan nilai absorbansi tertinggi yaitu 1,779. Analisis $P S A$ menunjukkan ukuran rata-rata nanopartikel emas sebesar $51,87 \mathrm{~nm}$ dan nilai $P Z C$ sebesar $-19,2 \mathrm{mV}$. Hasil FT-IR menunjukkan adanya interaksi pada gugus hidroksil pada ekstrak daun ilalang dengan ion $\mathrm{Au}^{3+}$, terlihat adanya pergeseran bilangan gelombang dari $3354 \mathrm{~cm}^{-1}$ menjadi $3390 \mathrm{~cm}^{-1}$. Berdasarkan analisis TEM menunjukkan morfologi nanopartikel emas berbentuk sphere dengan ukuran partikel rata-rata $20 \mathrm{~nm}$. Hasil perhitungan XRD menunjukkan ukuran kristalit nanopartikel emas sebesar 15,47 nm.
\end{abstract}

Kata Kunci: Imperata cylindrica L, Nanopartikel Emas (GoldNPs), Green Synthesis 


\section{INTRODUCTION}

The recent of gold nanoparticles successful in the synthesis with variations particle size between $1-100 \mathrm{~nm}$. Au nanoparticles have several advantages in such fields as catalysts [1], antibacterial [2], sensors [3] and drug delivery [4]. In addition to having superior properties, AuNPs also has a good particle size stability. Capping agent serves as a stabilizer particle size. Capping agent frequently used in the synthesis of AuNPs is polyvinyl pyrrolidone (PVP) [5], Cetyltrimethylammonium bromide/sodium dodecyl sulfate (CTAB / SDS) [6] and alginate [7].

In addition to capping agents, the formation of gold nanoparticles involves reducing compounds. Are usually, the reduction agents in the synthesis of AuNPs used sodium borohydrate $\left(\mathrm{NaBH}_{4}\right)$ [8], sodium citrate [9]. The use of chemical reducing is very harmful to the environment. To reduce the chemical reduction, the researchers successful to synthesized of gold nanoparticles using green chemistry method by utilizing natural bioreduktor that is environmentally friendly such as leaves extract of Bacopa monnieri extract [10], Rosa rugosa [11], and Euphorbia hirta L [12], Tinospora crispa leaf extract successfully used as reducing agent and capping agent in the synthesis of gold nanoparticles [13]. Secondary metabolites such as alkaloids, flavonoids, tannins, steroids, that contained at plant extracts very important role in the formation of gold nanoparticles. So far there has never been a synthesis of gold nanoparticles using leaf extracts of Imperata cylindrica $\mathrm{L}$.

Imperata cylindrica $\mathrm{L}$ is a plant in Indonesia has antioxidant properties and used as a herbal medicine. During this time, the Imperata cylindrica L plant are only used as animal feed and include disturbing weeds. The result of phytochemical test showed that secondary metabolites content at Imperata cylindrica L leaves is alkaloid, flavonoid, Tannins, steroids. Contained a flavonoid and the secondary metabolites the functioning act as reduction ion $\mathrm{Au}^{3+}$ into $\mathrm{Au}^{0}$ [13]. From the background and literature, the research aims to knows effect of concentration variation of Imperata cylindrica $\mathrm{L}$ leaf extract on synthesis process of gold nanoparticles. Utilization of Imperata cylindrica L leaf extract is expected to be used as reductant on synthesis process of gold nanoparticles.

\section{EXPERIMENTAL METHOD}

\section{Materials}

Synthesis of gold nanoparticles using $\mathrm{HAuCl}_{4}$ precursor, Imperata cylindrica L leaf extract, methanol, n-hexane, ethyl acetate pro analysis and aquadest. The sample using Imperata cylindrica L (ICL) were taken from Universitas Indonesia area.

\section{Methods}

As much $50 \mathrm{~g}$ ICL washed with water and dried for 7 days. The ICL were crushed using a blender to produce a powder. As much $25 \mathrm{~g}$ ICL powder macerated using $100 \mathrm{~mL}$ of methanol for 7 days. Filtrate the result of maceration in the extracted using $n$-hexane, ethyl acetate and water. The results of water fraction ICL leaf in the phytochemical test to determine of secondary metabolites such as alkaloids, flavonoids, steroids, tannins, saponins and polyphenols.

Taken as much $5 \mathrm{ml}$ solution $\mathrm{HAuCl}_{4} 7 \times 10^{-4} \mathrm{M}$ was added $1 \mathrm{~mL}$ of ICL extract solution water fraction (extract concentration variations code $1-5$ is $0.692 ; 1.384$; $2.076 ; 2.768 ; 3.46 \%)$. The solution was reacted at room light for 1 hour. The formation of gold nanoparticles be marked by color changes from yellow to red purple.

Characterization of gold nanoparticles using Shimadzu UV-Vis Spectrophotometer 2600 with wavelength from 200-800 nm set and equipped with wolfram lamp as a light source, functional group contained in extracts of Imperata cylindrica L leaf extract were characterized using Shimadzu Fourier Transform Infrared (FT-IR) Spectroscopy Prestige 21 with wavenumber from $400-4000 \mathrm{~cm}^{-1}$ set, and used a nernst lamp. The size distribution and particle charge GoldNPs were characterized using Particle Size Analyzer (PSA) and Zeta Potential (PZC) Malvern ZEN 1600 with dynamic light scattering system. The shape morphology and particle size of GoldNPs characterized by Transmission Electron Microscopy (TEM) JEM 1400 and using $350 \mathrm{keV}$ of electron beam energy. Crystallite size and crystalline GoldNPs in characterization with Shimadzu X-Ray Diffraction (XRD) 610 with Cobalt us a electron source.

\section{RESULTS AND DISCUSSION}

The phytochemical test showed a positive flavonoids, polyphenols and tannins. The synthesis
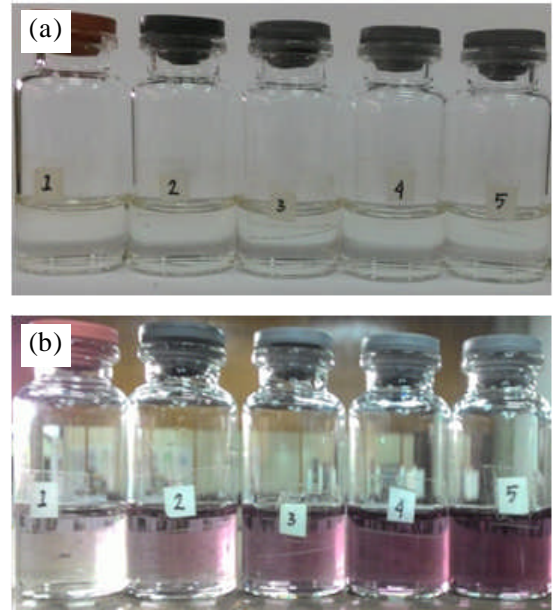

Figure 1. GoldNPs with a variety of extracts from left to right 1-5 (a) before and (b) after reaction. 
of gold nanoparticles showed a color change from yellow to red purple it indicates the formation of gold nanoparticles. Figure 1 shows the conditions synthesis process of gold nanoparticles. GoldNPs formation process is a reduction and oxidation. The mechanism is Equalition (1).

$$
\mathrm{Au}^{3+}+3 \mathrm{e}^{-} \rightarrow \mathrm{Au}^{0}
$$

$\mathrm{HAuCl}_{4}$ solution used as the $\mathrm{Au}^{3+}$ ion source and has a $216 \mathrm{~nm}$ absorbance value [14]. The reaction of gold nanoparticles formed for 1 hour at room temperature. The best concentration of Imperata cylindrica L leaf extract is $3,46 \%$. The color is more purple seen of Figure $1 \mathrm{~b}$ code 5 . The absorbance measurements using UV-Vis spectrophotometer was performed in the wavelength range $200-800 \mathrm{~nm}$. Figure 2 shows the UV-Vis spectrum of GoldNPs colloid synthesized with various concentrations of ICL extracts. The qualitative secondary metabolites contained the extracts of ICL have UV-Vis spectrum at wavelength of about 250-350 nm. Flavonoid compounds containing aromatic conjugated system and can show strong absorption band in the UV region. From UV-Vis spectra (Figure 2(a)) shows the concentration of ICL extract are best a value of $3.46 \%$ because has absorbance value of 1,779 and a wavelength of $530 \mathrm{~nm}$. Synthesis process of gold nanoparticles influenced by
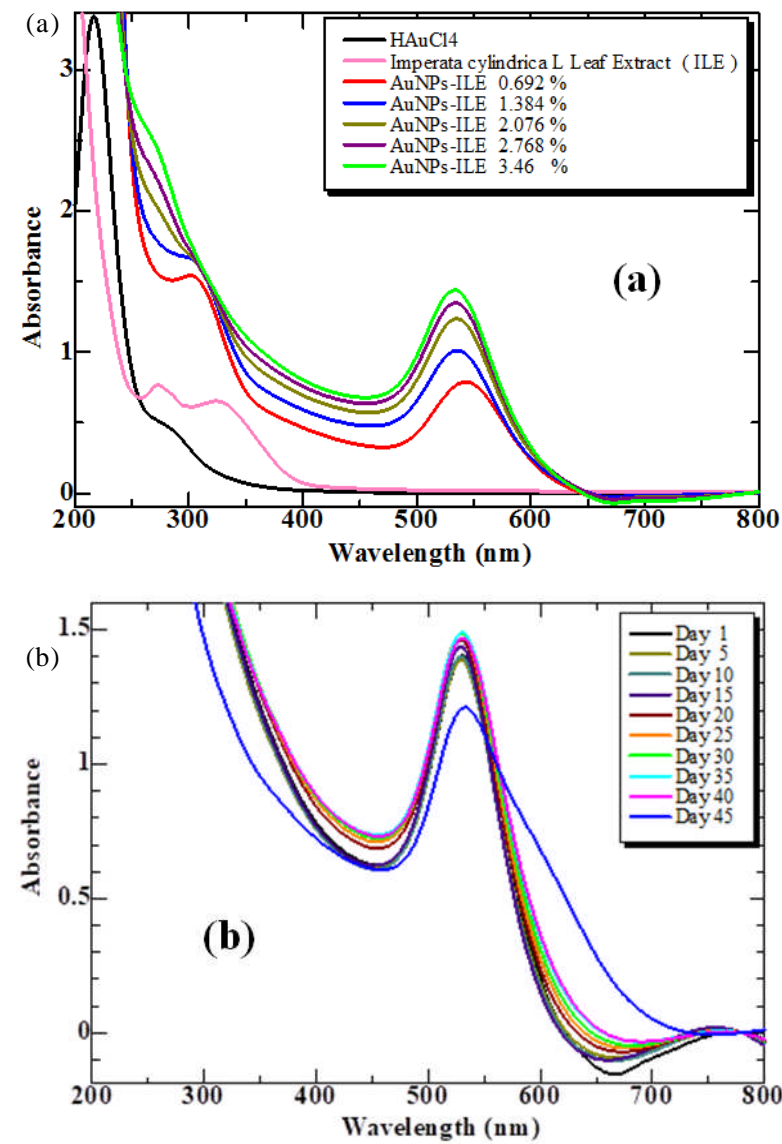

Figure 2. UV-Vis spectra GoldNPs (a) various concentrations of the extract and (b) the stability of GoldNPs. reaction time. The longer of reaction time at synthesis process of gold nanoparticles, increasingly much of nanoparticles are formed and the higher at absorbance value [15]. The best results are further characterized.

Gold nanoparticles have Surface Plasmone Resonance value when interaction with visible light [16]. Figure 2(b) shows the gold nanoparticles formed as stable for 40 days. Day 45 absorbance significant decline, indicated agglomeration happen at gold nanoparticles.

FT-IR shows the presence of -OH groups at ICL extracts can ion reduction $\mathrm{Au}^{3+}$ into $\mathrm{Au}^{0}$. In addition, the hydroxyl groups may act as a capping agent in the formation of gold nanoparticles. Indicated by the shift of the hidroxyl group at wavenumber $3354 \mathrm{~cm}^{-1}$ to $3390 \mathrm{~cm}^{-1}$ shown in Figure 3(a). The presence of more electronegative oxygen at carbonyl group that interaction with $\mathrm{Au}^{0}$ induce a shift wavenumber of $1720 \mathrm{~cm}^{-1}$ to $1751 \mathrm{~cm}^{-1}$ so that it takes more energy to perform vibration in group $\mathrm{C}=\mathrm{O}$ [17].

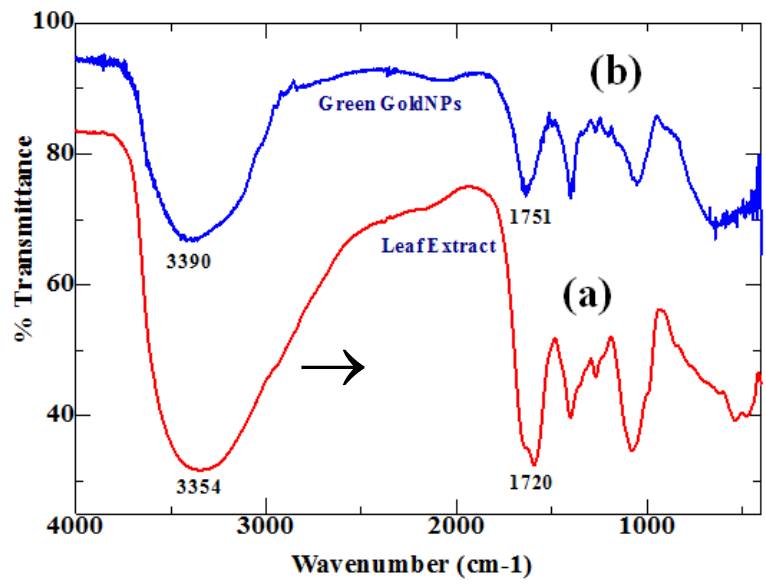

Figure 3. FT-IR spectra of (a) Imperata cylindrica L leaf extract and (b) GoldNPs.

TEM characterization was performed to determine the morphological form, density difference and GoldNPs particle size.

The analysis using TEM on GoldNPs sample which was successfully synthesized using ICL leaf extract with concentration of $3.46 \%$ and $\mathrm{HAuCl}_{4} 7 \times 10^{-4}$ $\mathrm{M}$ is shown in Figure 4. The TEM results show that the

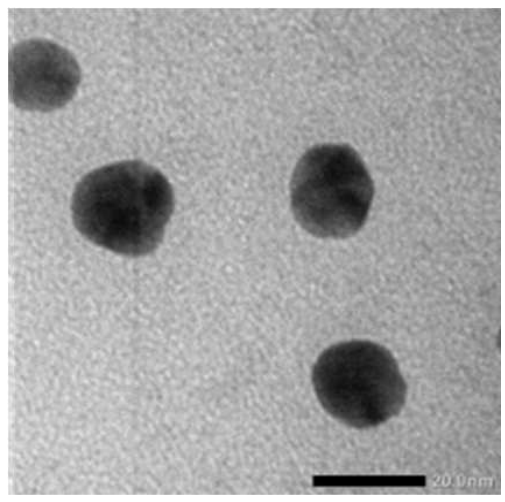

Figure 4. TEM of GoldNPs 
Effect of Concentration of Imperata Cylindrica L Leaf Extract on Synthesis Process of Gold Nanoparticles (Iwan Syahjoko Saputra)

resulting GoldNPs particles are sphere and have good homogeneity. The morphology of GoldNPs is strongly influenced by the diversity of secondary metabolites in the extract. The GoldNPs core has an evenly distributed active side that causes the GoldNPs to be spherical shape [18]. The existence of the intermediate particles force (shown on the PSA results that have a negative potential zeta value) will produce a good distribution and will reduce the occurrence of agglomeration [19]. GoldNPs have higher density than capping agent. Seen GoldNPs have darker images because they have a greater density than a capping agent and have a particle size of $\pm 20 \mathrm{~nm}$ at $150000 \mathrm{x}$ times magnifications.

Measurements using PSA and Zeta Potential function to know the average distribution of particle size and charge on a particle system. PSA showed the one peaks which states the intensity of distribution particle size (Figure 5(a)). At the peak has a particle size of $51.87 \mathrm{~nm}$ with $70.3 \%$ intensity. The capping agent from Imperata cylindrica $\mathrm{L}$ can be used as an stabilizing of GoldNPs [20].
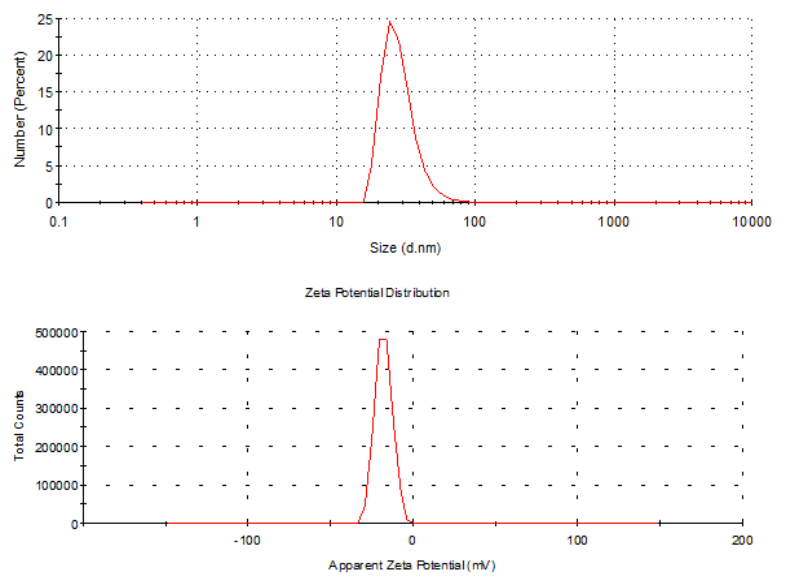

Figure 5. Spectrum image of GoldNPs (a) PSA, (b) PZC.

Zeta potential is measured using a zetasizer and zeta potential value associated with the stability of a dispersed particle. Result of PZC characterization showed the potential value of $-19.2 \mathrm{mV}$ for gold nanoparticles (Figure 5(b)). This indicated the repulsion style force between of particles of $-19.2 \mathrm{mV}$. The more negative results of potential zeta value the stronger particles force, the less agglomeration occurs [21].

The XRD showed a peak appearing at $2 \theta: 38.12$; $44.44 ; 64.79$ and 77.79 respectively (Figure 6). The value of corresponding from the JCPDS No. 65-2870. Gold which has a miller index (111), (200), (220) and (311) and $2 \theta$ is $38.18 ; 44.39 ; 64,65 ; 77.54$ respectively [22]. Based on calculations using Scherrer equation obtained an average crystallite size of gold nanoparticles is \pm 15.47 $\mathrm{nm}$. Effect of Imperata cylindrica L proving the structure of GoldNPs to be Face Center Cubic (FCC) [23].

Further purification of the flavonoid fraction to strengthen the stability of gold nanoparticles.

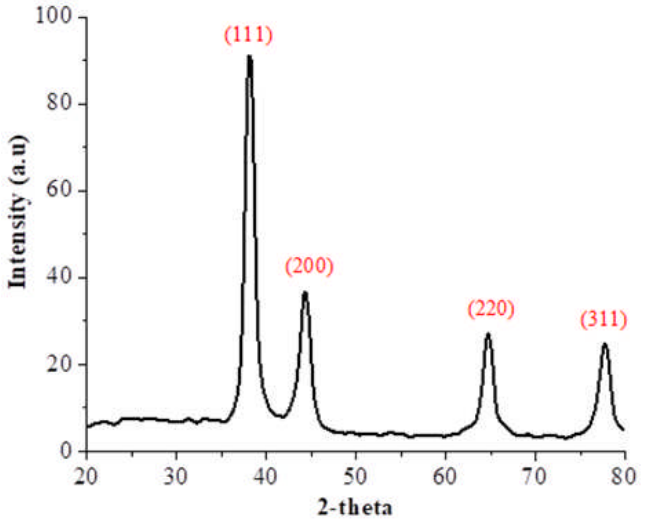

Figure 6. Pattern XRD of GoldNPs

\section{CONCLUSION}

Variations of Imperata cylindrica L leaf extracts are very influential on the process of synthesis of gold nanoparticles. The higher the ICL concentration given, the more $\mathrm{Au}^{3+}$ ions are reduced to $\mathrm{Au}^{0}$ (GoldNPs). The color change turns purple after the addition of ICL leaf extract for 1 hour reacts. Seen from result UV-Vis highest absorbance value that is on giving of extract $3,46 \%$. Leaf extract also serves as a capping agent for gold nanoparticles no agglomeration occurs. The value of -19.2 $\mathrm{mV}$ from PZC indicates a repulsive force between particles causing nanoparticles to not occur agglomeration and of the TEM image of the particle is well distributed with an average particle size of $20 \mathrm{~nm}$. The gold nanoparticles have an FCC crystal structure. From the existing research data can be concluded that gold nanoparticles successfully synthesized using Imperata cilyndrica L leaf extracts.

\section{ACKNOWLEDGMENTS}

This work was funded by Hibah PITTA 2016 from the Universitas Indonesia through the Directorate of Research and Community Services, Universitas Indonesia (No.2039/UN2.R12/HKP.05.00/2016).

\section{REFERENCES}

[1]. N.K.R Bogireddy. K.K.H. Anand and B.K. Mandal. "Gold Nanoparticles-Synthesis by Streculia Acuminate Extract and its Catalytic Efficiency in Alleviating Different Organic Dyes." Journal of Molecular Liquids, vol. 211, pp. 868-875, 2015.

[2]. C.G. Kumar. Y. Poornachandra and S.K. Mamidyala. "Green Synthesis of Bacterial Gold Nanoparticles Conjugated to Resveratrol as Delivery Vehicles." Colloids and Surfaces B: Biointerfaces, vol. 123, pp. 311-317, 2014.

[3]. Y. Li, J. Ma and Z. Ma. "Synthesis of Gold Nanostars with Tunable Morphology and their Electrochemical Application for Hydrogen 
Peroxide Sensing.” Electrochimica Acta, vol. 108, pp. 435-440, 2013.

[4]. G. Ajnai, A. Chiu, T. Kan, C.C. Cheng, T.H. Tsai and J.J. Chang. "Trends of Gold Nanoparticle-Based Drug Delivery System in Cancer Therapy." Exp Clin Med, vol. 6, no. 6, pp. 172-178. 2014.

[5]. Y.H. Won, K. Huh and L.A. Stanciu. "Au Nanospheres and Nanorods for Enzyme-free Electrochemical Biosensor Application." Biosensors and Bioelectronics, vol 26, pp.45144519, 2011.

[6]. S.Y. Moon, T. Kusunose and T. Sekino. "CTABAssisted Synthesis of Size- and Controlled Gold Nanoparticles in SDS Aqueous Solution." Materials Letters, vol. 63, pp.2038-2040, 2009.

[7]. F. Foliatini, Y. Yuliza and M.A.E. Hafizah. "Microwave- Assited Synthesis of AlginateStabillized Gold Nanoparticles." Makara J.Sci, vol. 18, no. 14, pp. 111-118, 2014.

[8]. P.K. Chen. G.J. Lee. S. Anandan. J.J. Wu. "Synthesis of $\mathrm{ZnO}$ and $\mathrm{Au}$ Tethered $\mathrm{ZnO}$ Pyramid-Like Microflower For Photocatalytic Degradation of Orange II." Materials Science and Engineering B, vol, 177, pp. 190-196, 2012.

[9]. H. Yu. H. Ming. H. Zhang. H. Li. K. Pan. Y. Li. F. Wang. J. Gong. Z. Kang. Au/ZnO Nanocomposites: Facile Fabrication and Enhanced Photocatalytic Activity for Degradation of Benzene. Materials Chemistry and Physics, vol, 137, pp. 113-117, 2012.

[10]. P.J. Babu. P. Sharma. S. Saranya. U. Bora. "Synthesis of Gold Nanoparticles using Ethonolic Leaf Extract of Bacopa monnieri and UV Irradiation." Materials Letters, vol. 93, pp.431-434, 2013.

[11]. S.P. Dubey, M. Lahtinen and M. Sillanpaa. "Green Synthesis and Characterizations of Silver and Gold Nanoparticles Using Leaf Extract of Rosa Rugosa." Colloids and Surfaces A, vol. 364, pp. 34-41, 2010.

[12]. A. Annamalai. V.L.P. Christina. D. Sudha. M. Kalpana. P.T.V. Lakshmi. "Green Synthesis, Characterization and Antimicrobial Activity of $\mathrm{Au}$ NPs Using Euphorbia hirta L. Leaf Extract" Colloids and Surfaces B: Biointerfaces, vol, 108, pp. 60-65, 2013.

[13]. D.O.B. Apriandanu, and Y. Yulizar. "The Role of Aqueous Leaf Extract of Tinospora crispa as Reducing and Capping Agents for Synthesis of Gold Nanoparticles.” In Proc. IOP Conf. Series: Materials Science and Engineering, pp. 188, 2017,.

[14]. Y. Yulizar. Foliantini. M. A. E. Hafizah. "A Facile and Effective Technique for the Synthesis of
Thiol-modified Au/Alginate Nanocomposite and Its Performance in Stabilizing Pickering Emulsion." Arabian Journal of Chemistry, vol. 05, 2016.

[15]. Yu. Li. Ya. Li. Q. Li. X. Fan. J. Gao. Y. Luo. "Rapid Biosynthesis of Gold Nanoparticles by the Extracellular Secretion of Bacillus niabensis 45: Characterization and Antibiofilm Activity." Journal Of Chemistry." Article ID 2781347, 2016.

[16]. K. Tahir. S. Nazir. B. Li. A.U. Khan. Z.U.H. Khan. P.Y. Gong. S.U. Khan. A. Ahmad. "Nerium oleander Leaves Extract Mediated Synthesis of Gold Nanoparticles and Its Antioxidant Activity." Materials Letters, vol, 156, pp. 198-201, 2015.

[17]. Y. Yulizar. T. Utari. H. A. Aryanta and D. Maulina. "Green Method for Synthesis of Gold Nanoparticles Using Polyscias scutellaria Leaf Extract Under UV Light and Their Catalytic Activity to Reduce Methylene Blue." Journal of Nanomaterials, Article ID 3079636, 2017.

[18]. A. R, Sadrolhosseini, S. A. Rashid. and A. Zakaria. "Synthesis of Gold Nanoparticles Dispersed in Palm Oil Using Laser Ablation Technique." Journal of Nanomaterials, Article ID 6496390, 2017.

[19]. M. P. Schrepler, L. David, L. Olenic, M. Potara, E. F. Fodor, P. Virag, F. I. Lucaci, I. Brie and A. Florea." Gold Nanoparticles Synthesized with a Polyphenols-Rich Extract from Cornelian Cherry (Cornus mas) Fruits: Effect on Human Skin Cells." Journal of Nanomaterials, Article ID 6986370, 2016.

[20]. V.J. Mohanraj and Y. Chen. "Nanoparticle-A Review." Tropical Journal of Pharmaceutical, vol. 5, no. 1, pp. 561-573, 2006.

[21]. Foliantini. Y. Yulizar. and M. A. E. Hafizah. "Theoretical Analysis of Interaction Energy in Alginate-Capped Gold Nanoparticles Colloidal System." Indo.J.Chem, vol. 14, no. 3. pp. 239-245, 2014.

[22]. B. Kumar. K. Smita. L. Cumbal. A. Debut. "One Pot Synthesis and Characterization of Gold Nanocatalyst using Sacha inchi (Plukenetia volubilis) oil." Green Approach. Journal of Photochemistry and Photobiology B: Biology, vol, 158, pp. 55-60, 2016.

[23]. K. X. Lee, K. Shameli, M. Miyake, N. Kuwano, N. Bahiyah, S. Eva and Y. P. Yew. "Green Synthesis of Gold Nanoparticles Using Aqueous Extract of Garcinia mangostana Fruit Peels." Journal of Nanomaterials, Article ID 8489094, 2016. 